\title{
Effect of Potassium-Boron Content of Leaf on Copra Yield of Coconut (Cocos nucifera L.) in Terai Region of West Bengal, India
}

\author{
N. Sathi Babu ${ }^{1 *}$, P.S. Medda ${ }^{1}$, K.Sinha $^{2}$ and A. Ghosh ${ }^{3}$ \\ ${ }^{1}$ Department of Plantation Crops and Processing, \\ ${ }^{2}$ Department of Soil Science and Agriculture Chemistry, ${ }^{3}$ Department of Agriculture Statistics, \\ Uttar Banga Krishi Viswavidyalaya, West Bengal, India \\ *Corresponding author
}

\section{A B S T R A C T}

Wide spread potassium and boron deficiency in coconut (Cocos nucifera L.) is a limiting factor for increased nut production in terai region of West Bengal. Accordingly, an experiment was undertaken in a $7.5 \mathrm{~m}$ x $7.5 \mathrm{~m}$ spaced 11 years old coconut plantation (cv.

\section{Keywords}

Potassium-boron, leaf, Coconut (Cocos nucifera L.), Terai

\section{Article Info}

Accepted: 07 January 2018 Available Online: 10 February 2018
ECT) laid out in Factorial randomized block design with 9 treatments and 4 replications with graded levels of potassium (900, 1200 and $1500 \mathrm{~g}$ of $\mathrm{K}_{2} \mathrm{O}$ per palm) and boron (25, 50, and $100 \mathrm{~g}$ borax/palm) for two consecutive years (2014-15 and 2015-16) to study the influence of leaf potassium and boron on copra yield in coconut in the region. The leaf samples collected from the index leaf $\left(14^{\text {th }}\right.$ frond) was taken for analysis of boron and potassium content at 6 and 12 months after soil application of both the nutrients. The results revealed that both leaf boron and potassium content increased significantly with increasing levels of applications. However, the intermediate dose of both the nutrients recorded the highest copra yield production $(15.74 \mathrm{~kg}$ per palm per year or 2.72 tonnes per ha per year) when leaf potassium and boron were $1.97 \%$ and $24.52 \mathrm{mg} / \mathrm{kg}$, respectively. With further increase in the rate of application of the nutrients, there was a decline in copra yield, despite an increase in the respective nutrient content in the leaves. The interaction effect also revealed the same trend. The copra yield production thus showed a positive correlation with increased content of leaf potassium and boron upto a certain level. And, both the nutrients produced a negative effect at 'more than optimum' doses in respect of copra yield.

\section{Introduction}

Since the last two decades, there has been a steady and consistent increase in the acreage under the cultivation of coconut (Cocos nucifera L.) in West Bengal. It is more so in the districts of North Bengal, where the palm is grown in homestead gardens, though the crop is gaining increasing importance of a plantation crop in the region. However, based on soils' inherent capacity to meet the plant's requirements, rational crop culture and nutrient management are very poorly practiced. Sandy soils, heavy rainfall, acidic nature of soil, nutrient removal by the crop, and leaching and percolation losses result in multiple nutrient deficiencies and makes the situation further complicated. Among the 
deficient plant nutrients in such coconut growing soils, potassium and boron are the most important. Both the nutrients play very significant roles in increasing the sizes of the nuts and copra biomass, enhance their softness, improve kernel development, help in translocation of starch from the leaves to the nuts, and increase the sweetness of the coconut water. Further, potassium helps regulating the plant's metabolism, closing and opening of the stomata required for water economy, acts as activator of many enzymes, maintains cation-anion balance of in the cell, and controls the transport of metabolites for cell division which in turn enhance the copra yield of coconut. Though such effects of the two nutrients are well known, studies on boron and potassium nutrition in coconut in the terai region of the West Bengal are not available.

Accordingly, the present investigation was undertaken to evaluate the effects of boron and potassium application to coconut in such soils and study their concentration in leaf and relate these concentrations to copra yield of the nuts.

\section{Materials and Methods}

The experiment was carried out during 201415 and 2015-16 at the Instructional Plots of the Department of Plantation Crops and Processing, Uttar Banga Krishi Viswavidyalaya, West Bengal. The experimental field is located at $43 \mathrm{~m}$ above mean sea level at $26^{\circ} 19^{\prime} 86^{\prime \prime} \mathrm{N}$ latitude and $89^{\circ} 23^{\prime} 53^{\prime \prime}$ E longitude. Physico-chemical properties of the soil analysed by standard methods were: texture- sandy loam, $\mathrm{pH}-5.45$ (Jackson, 1973), electrical conductivity - 0.06 dsm- $^{1}$ (Jackson, 1973), organic carbon 0.93\% (Walkley and Black, 1934), available N - 159. 32 kg/ha (Subbiah and Asija, 1956), available P - $23.15 \mathrm{~kg} / \mathrm{ha}$ (Bray and Kurtz, 1945), available $\mathrm{K}-87.15 \mathrm{~kg} / \mathrm{ha}$ (Jackson, 1967), and available B - $0.59 \mathrm{mg} / \mathrm{kg}$ (Hot water extractable as proposed by Berger and Truog (1939).

The experiment was laid out in Factorial Randomised Block Design with 9 treatments, with three different levels of potassium viz. $\mathrm{K}_{1}, \mathrm{~K}_{2}$, and $\mathrm{K}_{3} @ 900,1200$ and $1500 \mathrm{~g}$ of $\mathrm{K}_{2} \mathrm{O}$ (as MoP, $60 \% \mathrm{~K}_{2} \mathrm{O}$ ) and three levels of boron viz. $\mathrm{B}_{1}, \mathrm{~B}_{2}$, and $\mathrm{B}_{3} @ 25,50$, and $100 \mathrm{~g}$ (as borax, $10.5 \% \mathrm{~B}$ ) per palm per year at a spacing of $7.5 \times 7.5 \mathrm{~m}$ in 9 years old East Coast Tall. Each treatment was replicated 4 times The nine different treatment combinations were as follows: $\mathrm{T}_{1}: \mathrm{B}_{1} \mathrm{~K}_{1}: 25 \mathrm{~g}$ borax/palm + $900 \mathrm{~g} \mathrm{~K}_{2} \mathrm{O} /$ palm, $\mathrm{T}_{2}: \mathrm{B}_{1} \mathrm{~K}_{2:} 50 \mathrm{~g}$ borax/palm + $1200 \mathrm{~g} \mathrm{~K}_{2} \mathrm{O} /$ palm, $\mathrm{T}_{3}: \mathrm{B}_{1} \mathrm{~K}_{3:}: 25 \mathrm{~g}$ borax/palm + $1500 \mathrm{~g} \mathrm{~K}_{2} \mathrm{O} /$ palm, $\mathrm{T}_{4}: \mathrm{B}_{2} \mathrm{~K}_{1:}: 50 \mathrm{~g}$ borax/palm + $900 \mathrm{~g} \mathrm{~K}_{2} \mathrm{O} /$ palm, $\mathrm{T}_{5}: \mathrm{B}_{2} \mathrm{~K}_{2}: 50 \mathrm{~g}$ borax /palm + $1200 \mathrm{~g} \mathrm{~K}_{2} \mathrm{O} /$ palm, $\mathrm{T}_{6}: \mathrm{B}_{2} \mathrm{~K}_{3} 50$ g borax/palm + $1500 \mathrm{~g} \mathrm{~K}_{2} \mathrm{O} /$ palm, $\mathrm{T}_{7}: \mathrm{B}_{3} \mathrm{~K}_{1}$ : $100 \mathrm{~g}$ borax/palm $+900 \mathrm{~g} \mathrm{~K}$ O/palm, $\mathrm{T}_{8}$ : $\mathrm{B}_{3} \mathrm{~K}_{2:} 100 \mathrm{~g}$ borax/palm $+1200 \mathrm{~g} \mathrm{~K}$ O/palm and $\mathrm{T}_{9}: \mathrm{B}_{3} \mathrm{~K}_{3}: 100 \mathrm{~g}$ borax /palm $+1500 \mathrm{~g}$ $\mathrm{K}_{2} \mathrm{O} /$ palm. All the palms were fertilized uniformly with $500 \mathrm{~g} \mathrm{~N}$ (as urea, 46\% N) and $320 \mathrm{~g}$ of $\mathrm{P}_{2} \mathrm{O}_{5}$ (as SSP, $16 \% \mathrm{P}_{2} \mathrm{O}_{5}$ ) per palm along with the required amount of boron and potassium as per the treatment combinations. Half of the doses of the nutrients were applied in May, 2014 as pre-monsoon application, while the remaining half was applied in September, 2014 as post-monsoon application. The same fertilizer schedule was repeated for the year 2015. The fertilizers were applied at $180 \mathrm{~cm}$ away from the base of the palms (De Silva, 1968). The initial soil samples at 0-30 $\mathrm{cm}$ depth were collected at random before commencement of the study; thereafter, sampling was done at 6 month intervals at a the same depth at sites $1.8 \mathrm{~m}$ away from the trunk of the palm. For the determination of boron and potassium content of leaf, the leaf samples were collected from the index leaf i.e. $14^{\text {th }}$ fronds for analysis before application of the fertilizers and subsequently at 6 and 12 months after application. The $14^{\text {th }}$ fronds were 
chosen as the index leaf for analysis of as suggested by Reuter and Robinson (1997). The leaf samples were digested by tri-acid mixture and the acid digests as such or after proper dilution were analysed for their potassium content by flame photometry as described by Muhr et al., (1965). For determining boron, the digests were analysed by the method suggested by Berger and Truog (1939).

\section{Results and Discussion}

Effect of $K$ and $B$ application and their interactions on leaf $K$ content in coconut growing soils

Results with respect to the effect of application of boron at different levels on leaf $\mathrm{K}$ content are presented in Table 1 and Figure 1 showed that there was not much variation in leaf $\mathrm{K}$ content between the two years. The results of the two years were thus fairly consistent. With increase in the level of boron from $B_{1}$ to $B_{2}$, there was significant increase in leaf $\mathrm{K}$ content. Thus, the leaf $\mathrm{K}$ content increased from 1.72 at $\mathrm{B}_{1}$ level to $1.82 \%$ at $\mathrm{B}_{2}$ level at 6 months after application in the year 2014- 15. The increase in leaf $\mathrm{K}$ content thus increased with the additional supply of boron. Both $\mathrm{B}$ and $\mathrm{K}$ serve as buffers and are necessary for the maintenance of conducting tissues (Mengel and Kirkby, 2001).

This variation might be due to its maintenance of conducting tissues and cation - anion balance as a result of which cell membrane permeability to $\mathrm{K}^{+}$uptake was increased. Stimulation of the proton pump with subsequent hyper polarization of the membrane resulting in an increased driving force of $\mathrm{K}^{+}$influx may be another possible reason. Increased $\mathrm{K}$ uptake at an optimum level of soil boron has been reported by Samet et al., (2015) in pepper. With further increase in boron level, the leaf $\mathrm{K}$ content however, decreased substantially from $1.82 \%$ to $1.31 \%$ in the change from $B_{2}$ to $B_{3}$ level in 2014-15. This decrease was to the extent of about $28 \%$ and must be due to the toxic concentration of boron in the soil at $\mathrm{B}_{3}$ level of boron application. This negative effect between B and $\mathrm{K}$ might have been caused by $\mathrm{K}$ efflux out of the roots due to the differential effect of $B$ toxicity on plasma lemma permeability. Similar findings have been reported by Samet et al., (2015) and Mengel and Kirkby (2001) reported that excess supply of boron in growth medium reduced uptake of $\mathrm{K}$ and vice versa.

The results pertaining to the effect of $\mathrm{K}$ applications at different graded levels on the leaf $\mathrm{K}$ content are also depicted in Table 1 and Figure 2 revealed that with increase in the level of potassium from $\mathrm{K}_{1}$ to $\mathrm{K}_{2}$, there was significant increased from 1.12 to $1.74 \%$ in the leaf $\mathrm{K}$ content in 2014- 15 . The functions of potassium as already stated earlier might have contributed to the increased leaf $\mathrm{K}$ content at a higher potassium level. With further increase in potassium level, there was further increase in leaf $\mathrm{K}$ content from 1.74 to 1.99 in $2014-15$ from $K_{2}$ to $K_{3}$ and it may be because of 'more than required absorption of $\mathrm{K}$ as coconut is a potassium loving plant as reported by Manicot et al., (1980).

Increased requirement of $\mathrm{K}$ may also be due to its involvement in enzymatic activity, photosynthesis, stomatal movement, phloem transport, cation- anion balance and stress resistance (Marschner, 2012). The same trend of results was observed in 2015-16 and also in the case of pooled results for the two years. In any case, with increase in potassium supply, the nutrient continues to be increasingly absorbed as seen in increased leaf $\mathrm{K}$ content. This aspect is to be considered in coconut fertilisation for a high nut yield, since the absorbed $\mathrm{K}$ above a certain level does not give any additional yield. Venkitaswamy et al., (2011) also reported results in similar lines. 
Interaction effects of boron and potassium application on leaf $K$ content

The results revealed that the leaf $\mathrm{K}$ content was the highest in $\mathrm{B}_{1} \mathrm{~K}_{3}$ treatment followed by $\mathrm{B}_{2} \mathrm{~K}_{3}$ and $\mathrm{B}_{2} \mathrm{~K}_{2}$ treatments, being $2.32 \%, 2.21$ $\%$, and $1.96 \%$ respectively and it was lowest in $\mathrm{B}_{3} \mathrm{~K}_{1}$ followed by $\mathrm{B}_{1} \mathrm{~K}_{1}$ and $\mathrm{B}_{3} \mathrm{~K}_{3}$ amounting in the order of $0.97 \%, 1.10 \%$ and $1.43 \%$ in respective treatments in 2014-15 (Table 1 and Fig. 3). The same trend was observed in the year 2015-16 and also for the mean of the two years. Boron-potassium interactions at the applied rates and combinations might have caused the differences in the leaf $\mathrm{K}$ content. The results of the study suggest that, there was synergistic interaction effect between $\mathrm{K}$ and $\mathrm{B}$ in the case of $\mathrm{B}_{1} \mathrm{~K}_{3}, \mathrm{~B}_{2} \mathrm{~K}_{3}$, and $\mathrm{B}_{2} \mathrm{~K}_{2}$ treatments resulting in increased $\mathrm{K}$ uptake.

The interaction between these two nutrients was antagonistic also in $\mathrm{B}_{3} \mathrm{~K}_{1}$ and $\mathrm{B}_{3} \mathrm{~K}_{3}$ combinations. Findings in similar line in on leaf $\mathrm{K}$ contents in boron-potassium combinations have been reported by Mengel and Kirkby (2001).

The authors observed that $\mathrm{B}$ and $\mathrm{K}$ interaction was negative with an excess of boron; boron toxicity in case of excess boron application decreased the uptake of $\mathrm{K}$. It may be mentioned in this connection that Reuter and Robinson (1997) suggested 0.6, 0.6 to 0.9 , and 1.2 to $1.5 \mathrm{mg} / \mathrm{kg}$ leaf (14 ${ }^{\text {th }}$ leaf) $\mathrm{K}$ for confirming deficient, critical, and adequate ranges of potassium, respectively in coconut. Using these limits for ascertaining $\mathrm{K}$ deficiency or adequacy in coconut, it may be concluded that in the present study, the $\mathrm{B}_{3}$ and $\mathrm{K}_{1}$ levels and combined treatments of $\mathrm{B}_{1} \mathrm{~K}_{1}$, $\mathrm{B}_{2} \mathrm{~K}_{1}, \mathrm{~B}_{3} \mathrm{~K}_{1}$ were found to be in low range; further, $\mathrm{B}_{1}, \mathrm{~B}_{2}, \mathrm{~K}_{2} \mathrm{~K}_{3}$ levels and $\mathrm{B}_{1} \mathrm{~K}_{2}, \mathrm{~B}_{2} \mathrm{~K}_{2}$ and $\mathrm{B}_{3} \mathrm{~K}_{2}$ interactions were in sufficiency range, while, $\mathrm{B}_{1} \mathrm{~K}_{3}$ and $\mathrm{B}_{2} \mathrm{~K}_{3}$ interactions were found to be in the in excess or high range at 6 month after soil application of B and K. It may also concluded that, all the levels of boron and potassium and their interaction effects pertaining to leaf $\mathrm{K}$ content were showed progressively decreasing trend from 6 month to 12 months after soil application of boron and potassium, which might be attributed to consequent mobility of $\mathrm{K}$ ions from vegetative parts, such as the leaves, to the reproductive parts of the plants. These results are in tune with those of Harishkumar et al., (1982).

Effect of application of boron and potassium and their interactions on leaf $B$ content

Effect of boron application at different levels on leaf B content are presented in Table 2 and Figure 4 showed that with increase in the level of boron from $B_{1}$ to $B_{2}$, and from $B_{2}$ to $B_{3}$ there was significant increase in leaf boron content. B content in leaf increased from 14.09 to 22.58 and 22.58 to $30.79 \mathrm{mg} / \mathrm{kg}$ in respectively at 6 months after application in the year 2014-15.

The results further revealed that the increases in leaf $\mathrm{B}$ content were in proportion to the increases in the rates of application of boron. Similar results have been reported by Moura et al., (2013) in coconut.

The results with respect to the effect of graded levels applications of potassium on the leaf B content are also presented in Table 2 and Figure 5 revealed that there was high consistency in leaf B content between the results of the two years. With increase in the level of potassium from $\mathrm{K}_{1}$ to $\mathrm{K}_{2}$, there was little increase in the leaf boron content from 23.63 to 23.78 in $2015-16$ at 6 months after application and it was statistically at par with each other. With further increase in potassium level, there was sharp decrease in boron content of the leaves from 23.78 to 21.05 in 2015-16 and it was statistically significant. 
Table.1 Effect of application of boron and potassium and their interaction on leaf K content (\%) after 6 and 12 months of application

\begin{tabular}{|c|c|c|c|c|c|c|}
\hline \multirow[b]{2}{*}{ Levels of Boron } & \multicolumn{3}{|c|}{6 months (December) } & \multicolumn{3}{|c|}{12 months (June) } \\
\hline & 2014-15 & 2015-16 & Pooled & 2014-15 & 2015-16 & Pooled \\
\hline $\mathbf{B}_{1}$ & 1.72 & 1.73 & 1.73 & 1.03 & 1.03 & 1.03 \\
\hline $\mathbf{B}_{2}$ & 1.82 & 1.84 & 1.83 & 1.06 & 1.05 & 1.06 \\
\hline $\mathbf{B}_{3}$ & 1.31 & 1.31 & 1.31 & 0.86 & 0.86 & 0.86 \\
\hline $\mathrm{SE}(\mathrm{m}) \pm$ & 0.01 & 0.01 & 0.01 & 0.01 & 0.01 & 0.01 \\
\hline $\mathrm{LSD}(\mathrm{P}=0.05)$ & 0.02 & 0.01 & 0.01 & 0.02 & 0.03 & 0.02 \\
\hline \multirow{2}{*}{$\begin{array}{l}\text { Levels of } \\
\text { Potassium }\end{array}$} & \multicolumn{3}{|c|}{6 months (December) } & \multicolumn{3}{|c|}{12 months (June) } \\
\hline & 2014-15 & 2015-16 & Pooled & 2014-15 & 2015-16 & Pooled \\
\hline $\mathbf{K}_{1}$ & 1.12 & 1.12 & 1.12 & 0.86 & 0.85 & 0.86 \\
\hline$K_{2}$ & 1.74 & 1.75 & 1.75 & 1.03 & 1.03 & 1.03 \\
\hline $\mathbf{K}_{\mathbf{3}}$ & 1.99 & 2.00 & 2.00 & 1.06 & 1.05 & 1.06 \\
\hline $\mathrm{SE}(\mathrm{m}) \pm$ & 0.01 & 0.01 & 0.01 & 0.01 & 0.01 & 0.01 \\
\hline LSD $(P=0.05)$ & 0.02 & 0.01 & 0.01 & 0.02 & 0.03 & 0.02 \\
\hline
\end{tabular}

\begin{tabular}{|c|c|c|c|c|c|c|}
\hline \multirow[t]{2}{*}{ Treatments } & \multicolumn{3}{|c|}{6 months (December) } & \multicolumn{3}{|c|}{12 months (June) } \\
\hline & 2014-15 & 2015-16 & Pooled & 2014-15 & 2015-16 & Pooled \\
\hline $\mathbf{B}_{1} K_{1}$ & 1.10 & 1.10 & 1.10 & 0.83 & 0.83 & 0.83 \\
\hline $\mathbf{B}_{1} \mathbf{K}_{2}$ & 1.75 & 1.75 & 1.75 & 1.04 & 1.03 & 1.03 \\
\hline $\mathbf{B}_{\mathbf{I}} \mathbf{K}_{3}$ & 2.32 & 2.33 & 2.33 & 1.22 & 1.22 & 1.22 \\
\hline $\mathbf{B}_{2} \mathbf{K}_{1}$ & 1.29 & 1.30 & 1.29 & 0.99 & 0.98 & 0.98 \\
\hline $\mathbf{B}_{2} \mathbf{K}_{2}$ & 1.96 & 1.97 & 1.97 & 1.10 & 1.10 & 1.10 \\
\hline $\mathbf{B}_{2} \mathbf{K}_{3}$ & 2.21 & 2.24 & 2.23 & 1.10 & 1.08 & 1.09 \\
\hline $\mathbf{B}_{3} \mathbf{K}_{1}$ & 0.97 & 0.97 & 0.97 & 0.75 & 0.75 & 0.75 \\
\hline $\mathbf{B}_{3} \mathbf{K}_{2}$ & 1.52 & 1.53 & 1.52 & 0.96 & 0.96 & 0.96 \\
\hline $\mathbf{B}_{3} \mathbf{K}_{3}$ & 1.43 & 1.44 & 1.43 & 0.85 & 0.86 & 0.86 \\
\hline $\mathrm{SE}(\mathrm{m}) \pm$ & 0.01 & 0.01 & 0.01 & 0.01 & 0.02 & 0.01 \\
\hline LSD $(P=0.05)$ & 0.04 & 0.02 & 0.02 & 0.03 & 0.04 & 0.03 \\
\hline
\end{tabular}


Table.2 Effect of application of boron and potassium and their interaction on leaf B content (mg/kg) after 6 and 12 months of application

\begin{tabular}{|c|c|c|c|c|c|c|}
\hline \multirow[t]{2}{*}{ Levels of Boron } & \multicolumn{3}{|c|}{6 months (December) } & \multicolumn{3}{|c|}{12 months (June) } \\
\hline & 2014-15 & 2015-16 & Pooled & 2014-15 & 2015-16 & Pooled \\
\hline$B_{1}$ & 14.09 & 14.52 & 14.30 & 8.932 & 9.034 & 8.983 \\
\hline $\mathbf{B}_{2}$ & 22.58 & 22.67 & 22.62 & 11.785 & 12.045 & 11.915 \\
\hline $\mathbf{B}_{3}$ & 30.79 & 31.27 & 31.03 & 14.766 & 14.61 & 14.688 \\
\hline $\mathrm{SE}(\mathrm{m}) \pm$ & 0.16 & 0.19 & 0.15 & 0.25 & 0.25 & 0.22 \\
\hline$\overline{L S D}(\mathrm{P}=0.05)$ & 0.48 & 0.56 & 0.43 & 0.72 & 0.73 & 0.63 \\
\hline Levels of & \multicolumn{3}{|c|}{6 months (December) } & \multicolumn{3}{|c|}{12 months (June) } \\
\hline Potassium & 2014-15 & 2015-16 & Pooled & 2014-15 & 2015-16 & Pooled \\
\hline $\mathbf{K}_{1}$ & 23.22 & 23.63 & 23.42 & 12.25 & 12.34 & 12.29 \\
\hline $\mathbf{K}_{2}$ & 23.24 & 23.78 & 23.51 & 12.39 & 12.37 & 12.38 \\
\hline$K_{3}$ & 21.00 & 21.05 & 21.02 & 10.84 & 10.98 & 10.91 \\
\hline $\mathrm{SE}(\mathrm{m}) \pm$ & 0.16 & 0.19 & 0.15 & 0.25 & 0.25 & 0.22 \\
\hline LSD $(P=0.05)$ & 0.48 & 0.56 & 0.43 & 0.72 & 0.73 & 0.63 \\
\hline \multirow[t]{2}{*}{ Treatments } & \multicolumn{3}{|c|}{6 months (December) } & \multicolumn{3}{|c|}{12 months (June) } \\
\hline & 2014-15 & 2015-16 & Pooled & 2014-15 & 2015-16 & Pooled \\
\hline $\mathbf{B}_{1} \mathbf{K}_{1}$ & 14.22 & 14.73 & 14.47 & 9.60 & 9.48 & 9.54 \\
\hline $\mathbf{B}_{1} \mathbf{K}_{2}$ & 15.73 & 15.98 & 15.85 & 9.98 & 10.26 & 10.12 \\
\hline $\mathbf{B}_{1} \mathbf{K}_{3}$ & 12.31 & 12.85 & 12.58 & 7.22 & 7.36 & 7.29 \\
\hline $\mathbf{B}_{2} \mathbf{K}_{1}$ & 22.08 & 22.32 & 22.20 & 11.39 & 11.76 & 11.58 \\
\hline $\mathbf{B}_{2} \mathbf{K}_{2}$ & 25.00 & 24.05 & 24.52 & 13.05 & 13.31 & 13.18 \\
\hline $\mathbf{B}_{2} \mathbf{K}_{3}$ & 20.67 & 20.05 & 20.36 & 10.91 & 11.06 & 10.99 \\
\hline $\mathbf{B}_{3} \mathbf{K}_{1}$ & 33.42 & 34.29 & 33.86 & 16.18 & 15.87 & 16.02 \\
\hline $\mathbf{B}_{3} \mathbf{K}_{2}$ & 28.93 & 29.28 & 29.11 & 13.72 & 13.45 & 13.58 \\
\hline $\mathbf{B}_{3} \mathbf{K}_{3}$ & 30.02 & 30.24 & 30.13 & 14.40 & 14.52 & 14.46 \\
\hline $\mathrm{SE}(\mathrm{m}) \pm$ & 0.28 & 0.33 & 0.25 & 0.43 & 0.43 & 0.37 \\
\hline LSD $(P=0.05)$ & 0.84 & 0.97 & 0.74 & 1.25 & 1.26 & 1.09 \\
\hline
\end{tabular}


Int.J.Curr.Microbiol.App.Sci (2018) 7(2): 398-410

\begin{tabular}{|c|c|c|c|c|c|c|}
\hline \multicolumn{4}{|c|}{$\begin{array}{l}\text { Table.3 Effect of application of boron and potassium and their } \\
\text { interaction on dry copra yield (kg per palm per year) }\end{array}$} & \multicolumn{3}{|c|}{$\begin{array}{l}\text { Effect of application of boron and potassium and } \\
\text { their interaction on dry copra yield (tons/ha/year) }\end{array}$} \\
\hline Levels of Boron & 2014-15 & 2015-16 & Pooled & 2014-15 & 2015-16 & Pooled \\
\hline $\mathbf{B}_{1}$ & 7.97 & 8.33 & 8.15 & 1.44 & 1.52 & 1.48 \\
\hline $\mathbf{B}_{2}$ & 11.73 & 12.38 & 12.06 & 2.09 & 2.30 & 2.19 \\
\hline $\mathbf{B}_{3}$ & 4.32 & 4.56 & 4.44 & 0.76 & 0.75 & 0.75 \\
\hline $\mathrm{SE}(\mathrm{m}) \pm$ & 0.29 & 0.25 & 0.26 & 0.06 & 0.05 & 0.04 \\
\hline $\operatorname{LSD}(P=0.05)$ & 0.84 & 0.73 & 0.76 & 0.18 & 0.14 & 0.13 \\
\hline Levels of Potassium & 2014-15 & $2015-16$ & Pooled & 2014-15 & 2015-16 & Pooled \\
\hline$K_{1}$ & 5.84 & 6.20 & 6.02 & 1.02 & 1.08 & 1.05 \\
\hline $\mathbf{K}_{2}$ & 10.41 & 10.98 & 10.69 & 1.78 & 1.89 & 1.84 \\
\hline $\mathbf{K}_{3}$ & 7.77 & 8.10 & 7.93 & 1.49 & 1.59 & 1.54 \\
\hline $\mathrm{SE}(\mathrm{m}) \pm$ & 0.29 & 0.25 & 0.26 & 0.06 & 0.05 & 0.04 \\
\hline $\operatorname{LSD}(\mathrm{P}=0.05)$ & 0.84 & 0.73 & 0.76 & 0.18 & 0.14 & 0.13 \\
\hline Treatments & 2014-15 & 2015-16 & Pooled & 2014-15 & 2015-16 & Pooled \\
\hline $\mathbf{B}_{1} \mathbf{K}_{1}$ & 6.22 & 6.56 & 6.39 & 1.10 & 1.18 & 1.14 \\
\hline $\mathbf{B}_{1} \mathbf{K}_{2}$ & 10.82 & 11.31 & 11.06 & 1.88 & 1.97 & 1.92 \\
\hline $\mathbf{B}_{\mathbf{I}} \mathbf{K}_{3}$ & 6.87 & 7.11 & 6.99 & 1.35 & 1.42 & 1.38 \\
\hline $\mathbf{B}_{2} \mathbf{K}_{1}$ & 7.58 & 8.13 & 7.85 & 1.31 & 1.44 & 1.37 \\
\hline $\mathbf{B}_{2} \mathbf{K}_{2}$ & 15.30 & 16.19 & 15.74 & 2.60 & 2.85 & 2.72 \\
\hline $\mathbf{B}_{2} \mathbf{K}_{3}$ & 12.30 & 12.84 & 12.57 & 2.37 & 2.60 & 2.49 \\
\hline $\mathbf{B}_{3} K_{1}$ & 3.71 & 3.90 & 3.81 & 0.65 & 0.62 & 0.64 \\
\hline $\mathbf{B}_{3} \mathbf{K}_{2}$ & 5.10 & 5.45 & 5.28 & 0.87 & 0.87 & 0.87 \\
\hline $\mathbf{B}_{3} \mathbf{K}_{3}$ & 4.13 & 4.35 & 4.24 & 0.76 & 0.75 & 0.76 \\
\hline $\mathrm{SE}(\mathrm{m}) \pm$ & 0.49 & 0.43 & 0.45 & 0.10 & 0.08 & 0.08 \\
\hline $\operatorname{LSD}(\mathrm{P}=0.05)$ & 1.45 & 1.27 & 1.31 & 0.31 & 0.24 & 0.22 \\
\hline
\end{tabular}


Fig.1 Effect of application of boron on leaf potassium content (\%) after 6 and 12 months of application

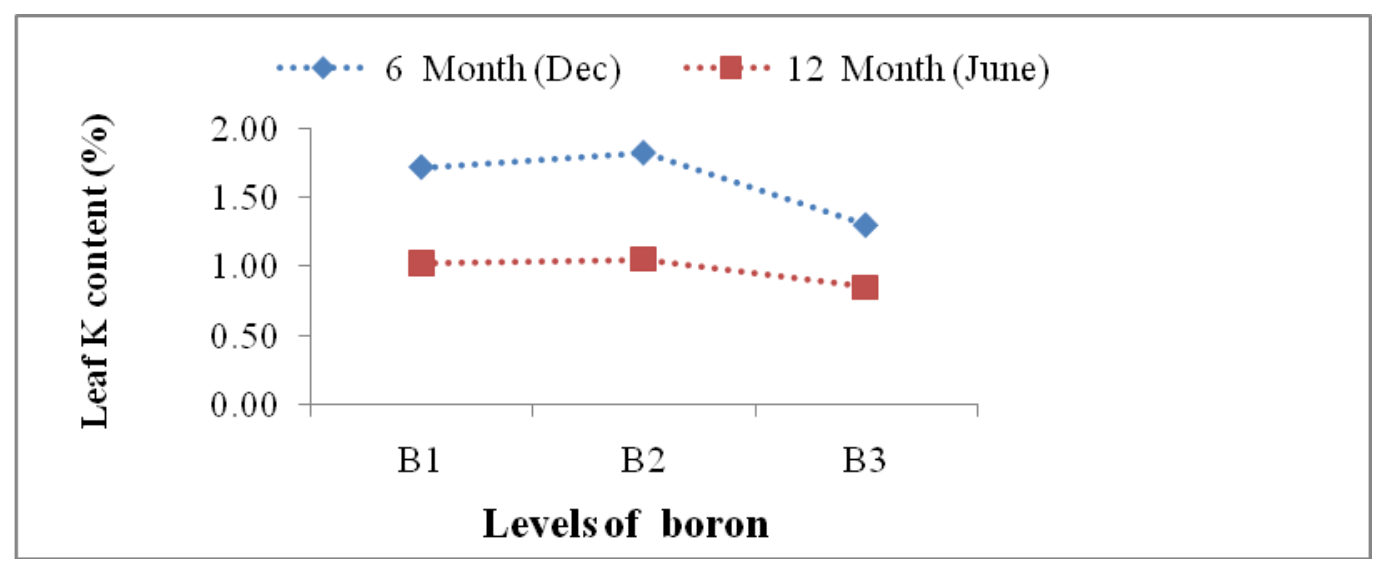

Fig.2 Effect of application of potassium on leaf potassium content (\%) after 6 and 12 months of application

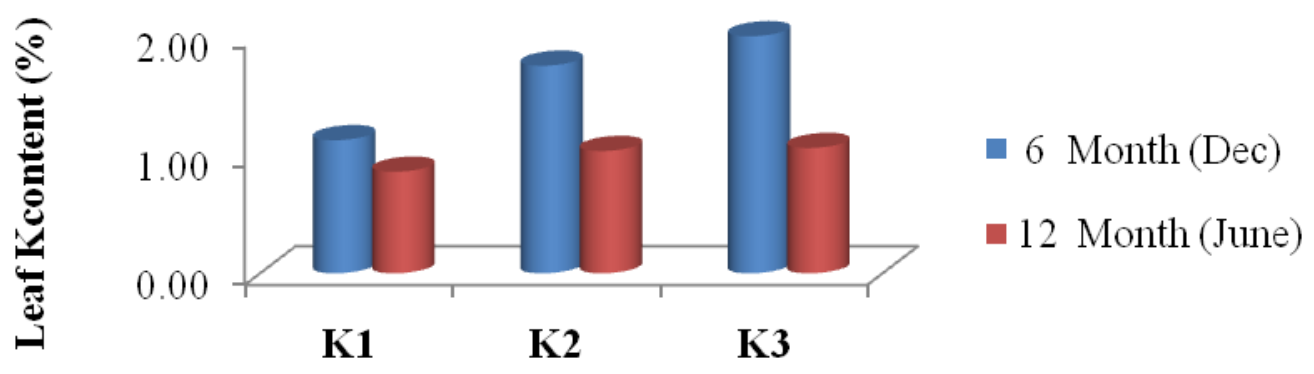

\section{Levels of potassium}

Fig.3 Interaction effect of boron and potassium on leaf potassium content (\%) after 6 and 12 months of application

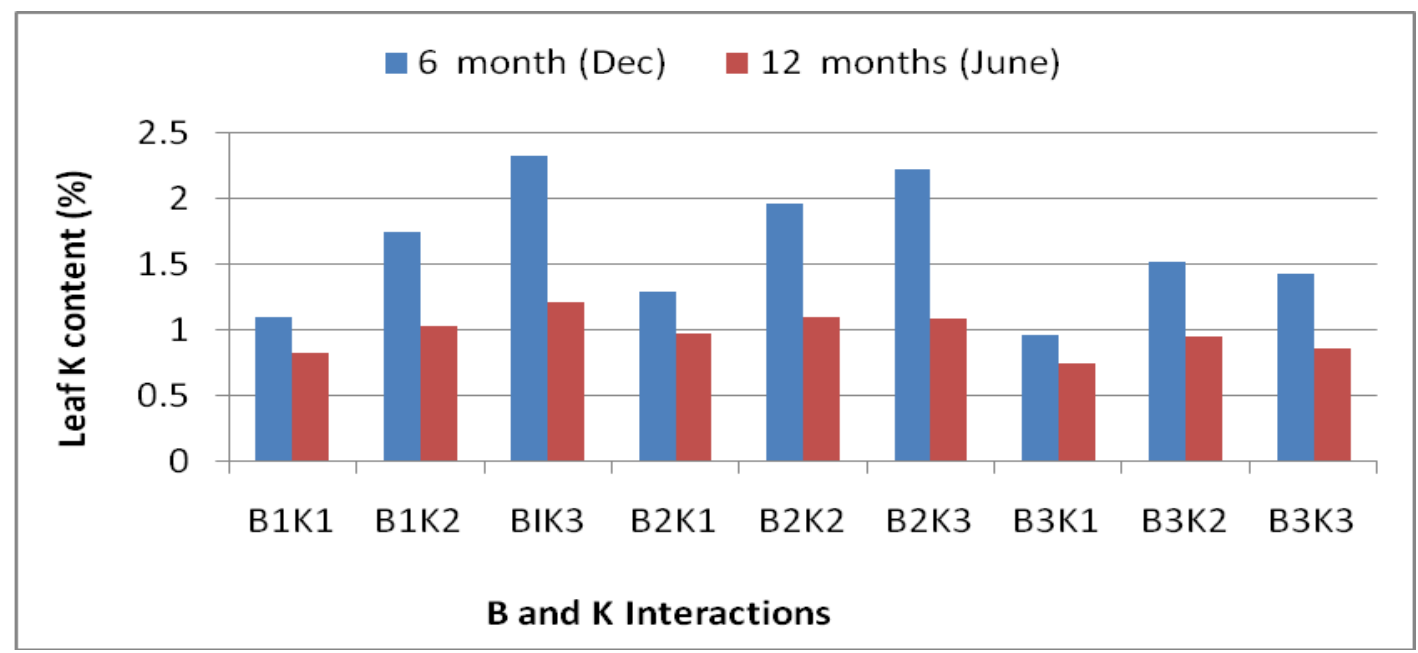


Fig.4 Effect of application of boron on leaf boron content $(\mathrm{mg} / \mathrm{kg})$ after 6 and 12 months of application

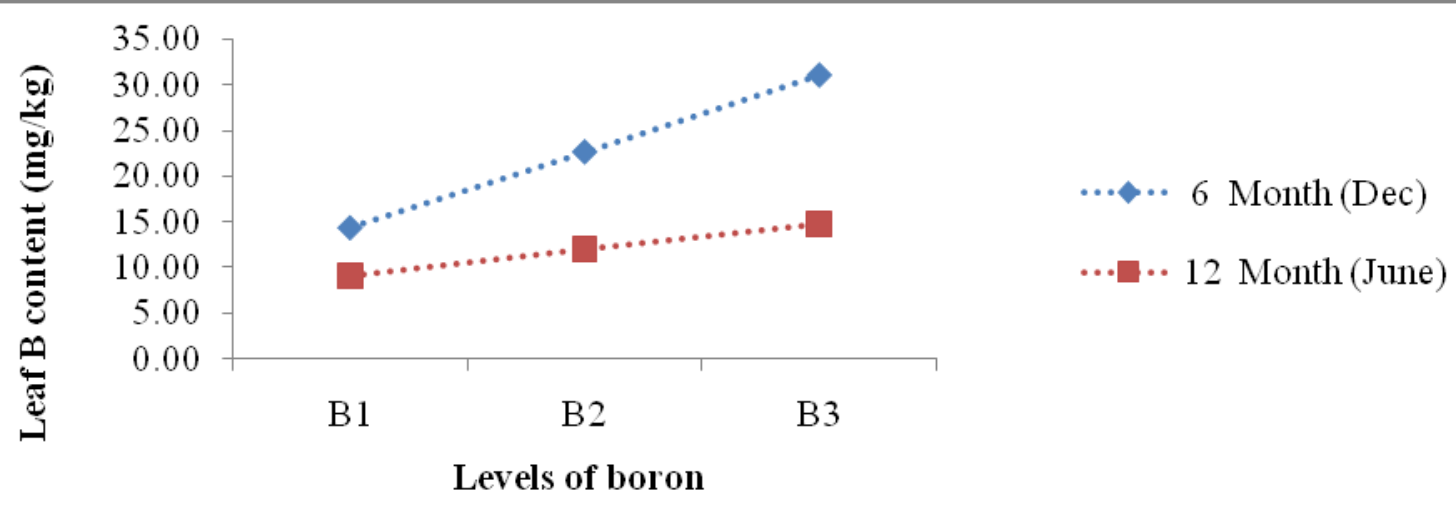

Fig.5 Effect of application of potassium on leaf boron content $(\mathrm{mg} / \mathrm{kg})$ after 6 and 12 months of application

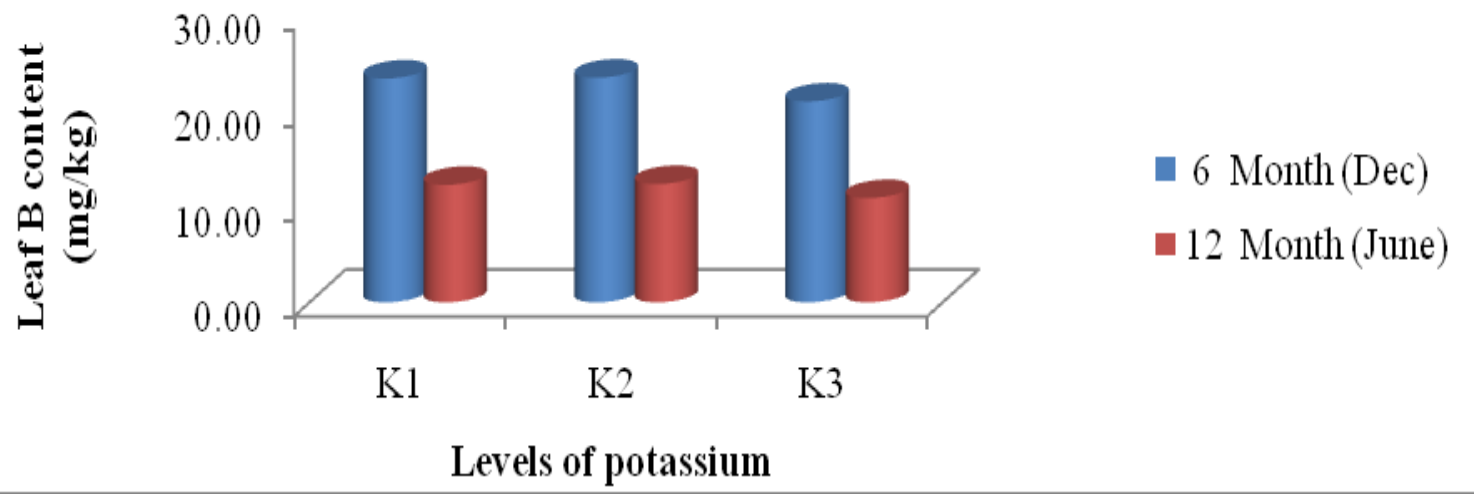

Fig.6 Interaction effect of boron and potassium on leaf boron content (mg/kg) after 6 and 12 months of application

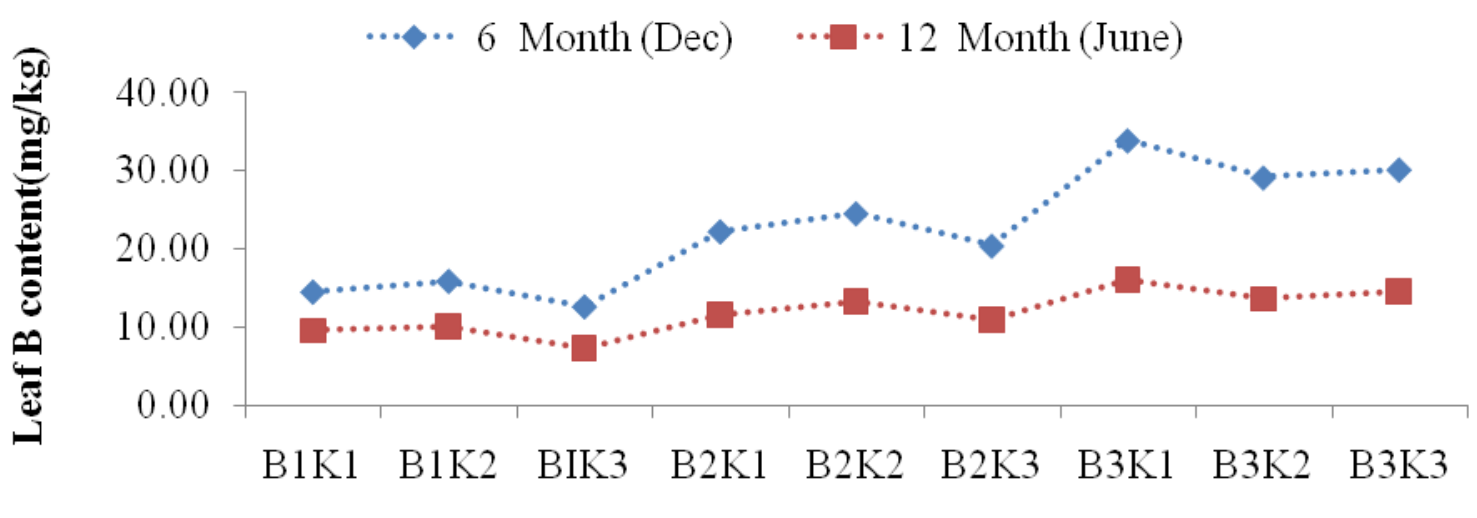

\section{$B$ and $K$ interactions}


Fig.7 Effect of boron on dry copra yield

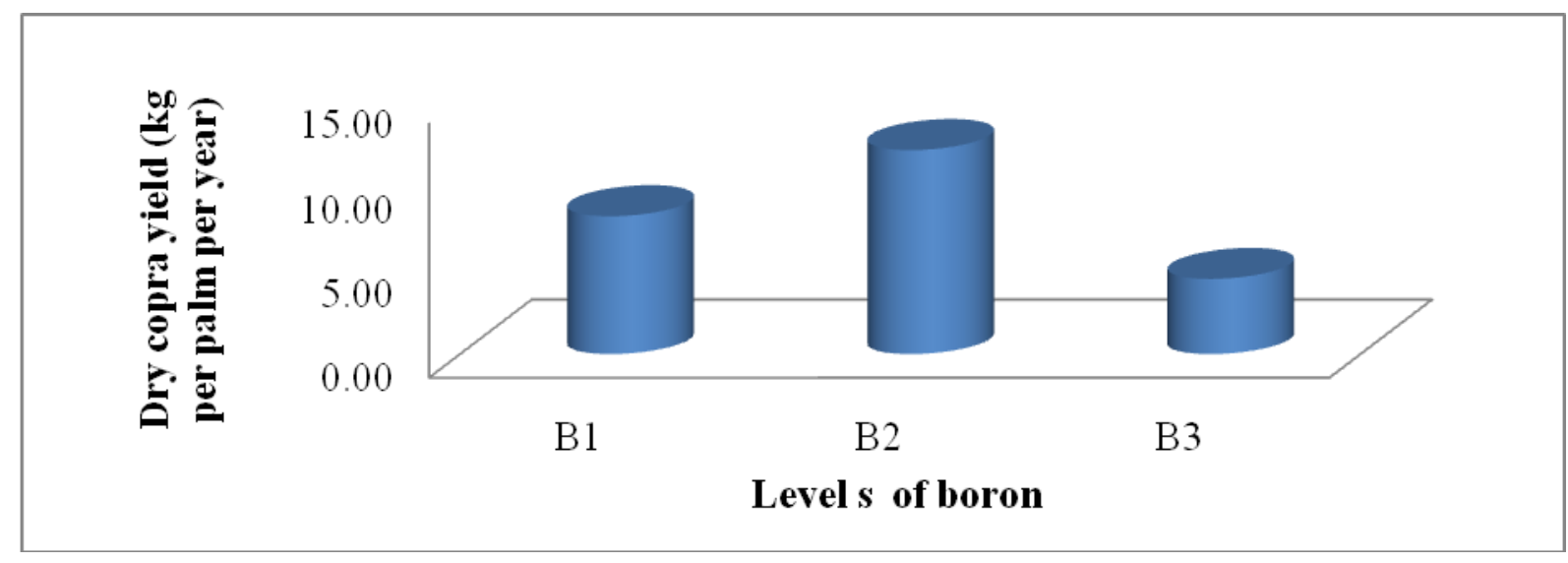

Fig.8 Effect of potassium on dry copra yield
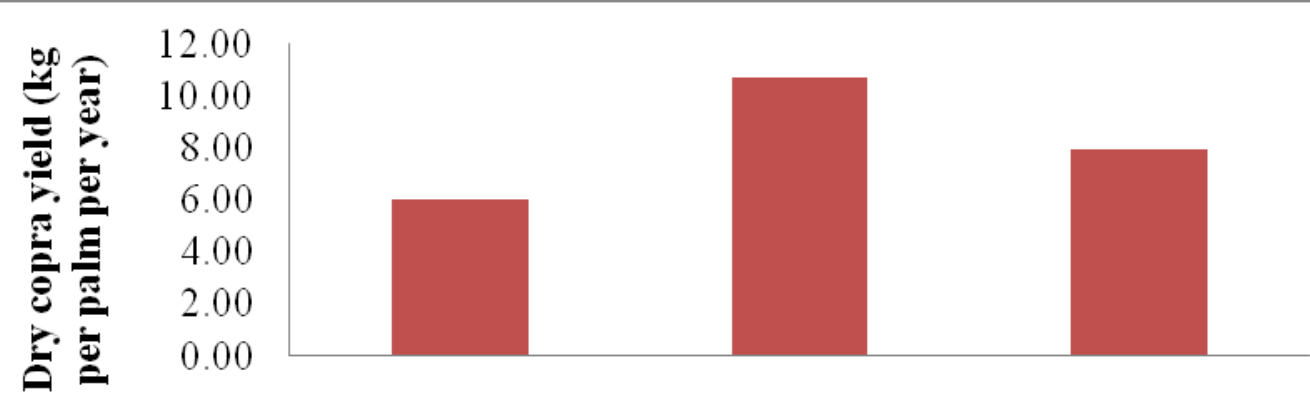

K1

$\mathrm{K} 2$

K3

\section{Levels of potassium}

Fig.9 Interaction effect of boron and potassium on dry copra yield

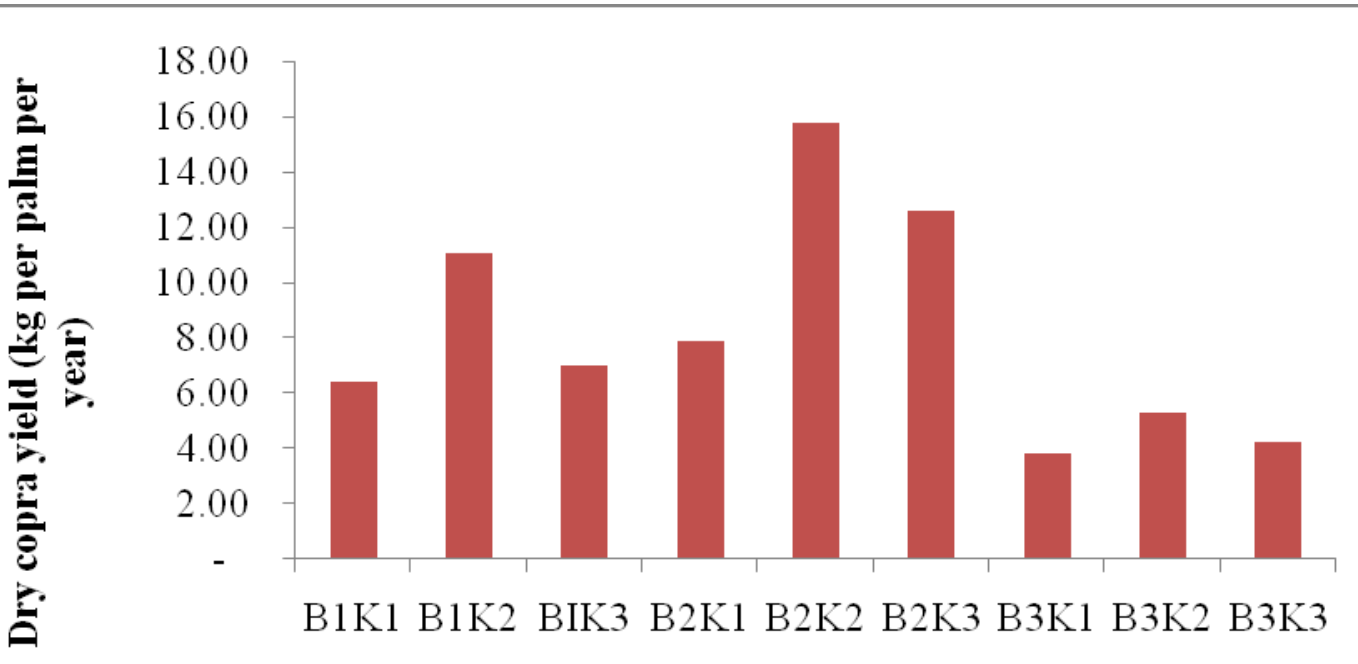

$B$ and $K$ interactions 
This variation might be due to negative interaction between $\mathrm{B}$ and $\mathrm{K}$ at excess levels of available $\mathrm{K}$ due possibly to cation-anion imbalance as has been reported earlier by Samet et al., (2015). The same trend was observed in 2014-15 and also in the case of pooled results for the two years. In any case, with increase in potassium supply, there was an increase in leaf boron content followed by significant increase at a certain boron level. This aspect is to be considered in coconut fertilisation so as to avoid boron toxicity in the coconut palms.

\section{Interaction effects of boron and potassium on leaf $B$ content}

A perusal of data presented in Table 2 and Figure 6 showed that the leaf B content was the highest in $\mathrm{B}_{3} \mathrm{~K}_{1}$ treatment followed by $\mathrm{B}_{3} \mathrm{~K}_{3}$ and $\mathrm{B}_{3} \mathrm{~K}_{2}$ treatments the leaf $\mathrm{B}$ content being 33.42, 30.02, and $28.93 \mathrm{mg} / \mathrm{kg}$ respectively and it was lowest in $\mathrm{B}_{1} \mathrm{~K}_{3}$, followed by $\mathrm{B}_{1} \mathrm{~K}_{1}$ and $\mathrm{B}_{1} \mathrm{~K}_{2}$ treatments respective leaf boron content was 12.31, 14.22 , and $15.73 \mathrm{mg} / \mathrm{kg}$ in $2014-15$. The same trend was observed in the year 2015-16 and also for the mean of the two years. B and $\mathrm{K}$ interactions at the applied rates and combinations might have caused the differences in the leaf B content. This type of effect may be due to excess application of potassium caused to decrease in leaf $B$ content. The results of the study suggest that as regards to leaf $\mathrm{B}$ content, there was synergistic interaction effect between potassium and boron in certain cases and antagonistic interaction in some cases. The synergistic combinations are to be adopted, and antagonistic combinations are to be avoided in applying fertilizers in coconut for maximising the nut yield of the plantation crop in terai region of West Bengal. The results of the study are in agreement with those of present findings confirmed the findings of Ranade-Malvi (2011).
Considering the leaf $\left(14^{\text {th }}\right)$ boron content ratings in coconut as suggested by Reuter and Robinson (1997), $\quad \mathrm{B}_{1} \mathrm{~K}_{1}, \quad \mathrm{~B}_{1} \mathrm{~K}_{2}$ and $\mathrm{B}_{1} \mathrm{~K}_{3}$ combination treatments were in low range, while, $\mathrm{B}_{2} \mathrm{~K}_{1}, \mathrm{~B}_{2} \mathrm{~K}_{2}$ and $\mathrm{B}_{2} \mathrm{~K}_{3}$ treatments were in adequate or sufficiency range at 6 month after soil application of B and K. At the same time period, the soils under the treatments viz. $\mathrm{B}_{3} \mathrm{~K}_{1}, \mathrm{~B}_{3} \mathrm{~K}_{2}$ and $\mathrm{B}_{3} \mathrm{~K}_{3}$ were in excess or high range of boron at 6 month after application of boron and potassium, suggesting that in such soils, boron reached toxic levels which cause toxicity effect, and boron should not be applied in coconut at such high rates. Further, it appears that the individual effects of boron and potassium and also their interaction effects pertaining to the leaf boron content had a decreasing trend from 6 to 12 months after soil application of boron and potassium. The continued decrease in leaf B content may because of the fact that during this period ( 6 to 12 months), boron might have been utilized in fruit setting, boosts up pollination, seed development, synthesis of cell wall, lignifications maintenances of cell wall structure integrity nitrogen metabolism, and protein biosynthesis. A similar result was also reported by Ahmad et al., (2009).

\section{Effect of $B$ and $K$ application and their interaction on copra yield}

\section{Effect of boron and potassium on copra yield}

The result in relation to the effect of boron applications at different levels on dry copra yield kg per palm per year and tons per ha per year are presented in Table 3 and Figure 7 showed that in both the years, the dry copra yield was the highest at $\mathrm{B}_{2}$ level of boron and with increase in boron level from $\mathrm{B}_{1}$ to $\mathrm{B}_{2}$, there was a substantial increase in dry copra yield (8.15 to $12.06 \mathrm{~kg}$ per palm per year and 1.48 to 2.19 tons per ha per year). Increase in dry copra yield was to the extent of about 
$32.4 \%$. With further increase in boron to $\mathrm{B}_{3}$ level, dry copra weight declined drastically (12.06 to $4.44 \mathrm{~kg}$ per palm per year and 2.19 to just 0.79 tons per ha per year). Presence of higher concentration of boron cause toxicity at $\mathrm{B}_{3}$ level appears to be the reason for the reduction in the dry copra yield. The results of the present study suggest that application of boron in coconut at $\mathrm{B}_{3}$ level therefore should never be applied.

Table 3 and Figure 8 present the results pertaining to the effect of potassium applications at different levels on dry copra yield. The results revealed that the dry copra yield increased from $K_{1}$ to $K_{2}$ level (6.02 to $10.69 \mathrm{~kg}$ per palm per year and 1.05 to 1.84 tons per ha per year). However, further increase in potassium supply from $\mathrm{K}_{2}$ to $\mathrm{K}_{3}$ level resulted in decreased dry copra yield (10.69 to $7.93 \mathrm{~kg}$ per palm per year and 1.84 to 1.54 tons per ha per year). Magat et al., (1976) stated that decreased copra yield per palm with increasing levels of potassium application.

\section{Interaction effects of boron and potassium on dry copra yield}

The results with respect to boron-potassium interaction effects on dry copra yield are presented in Table 3 and Figure 9. With respect to dry copra yield among the treatments, $\mathrm{B}_{2} \mathrm{~K}_{2}$ was performed and recorded highest (15.74 kg per palm per year and 2.72 tons per ha per year) followed by $\mathrm{B}_{2} \mathrm{~K}_{3}(12.57$ $\mathrm{kg}$ per palm per year 2.49 tons per ha per year) and $\mathrm{B}_{1} \mathrm{~K}_{2}$ (11.06 kg per palm per year and 1.92 tons per ha per year). At an optimum concentration of boron-potassium interaction for increased dry copra weight was higher in $\mathrm{B}_{2} \mathrm{~K}_{2}$ combination and beyond excess levels concentration of both nutrients showed negative result on copra yield which might be higher levels of boron with all levels of potassium impeded the availability of $\mathrm{K}$ from soil solution. The results suggest that for reaching the maximum dry copra yield, $\mathrm{B}_{2} \mathrm{~K}_{2}$ level may be adopted in terai zone of west Bengal.

\section{References}

Ahmad, W., Niaz, A., Kanwal, S.R. and Rasheed, M.K. 2009. Role of boron in plant growth: A review. Journal of Agricultural Research, 47: 329-338.

Berger, K. C. and Truog, E. 1939. Boron determination in soils and plants. Ind. Eng. Chem, 11: 540-545.

Bray, R. H. and Kurtz, L.T. 1945. Determination of total, organic and available forms of phosphorus in soils. Soil Science, 59: 39-45.

De Silva, M.A.T. 1968. Recommended methods of fertilizer application for coconut palms. Ceylon Coconut Planters, 3:108-111.

Harishkumar, P., Nair, B.P., Rakhiappan, P., Nagabhushanan, S. and Moham, E. 1982. Variation in mineral composition of leaves of cashew (Anacardium occidentale L.) as effected by season, position and age. Indian Cashew Journal, 14 (1): 7-10.

Jackson, M. 1973. Soil chemical analysis. Prentice hall of India private limited, New Delhi.

Jackson, M. L. 1967. Soil Chemical Analysis. Prentice-Hall of India, New Delhi.

Magat, S.S., Cadigal, V. L. and Habana, J.A. 1976. Yield Improvement of Coconut in an Elevated Inland Area of Davao by Potassium Chloride Fertilization. Philippine Journal of Crop Science, 1: 60-63.

Manciot, R. Ollagnier, M. and Ochs, R. 1980. Mineral nutrition and fertilization of the coconut around world. Oleagineux, 35 (1): 23-27. 
Marschner, H. 2012. In: Mineral Nutrition of Higher Plants. $3^{\text {rd }}$ edition. Academic Press, London. pp: 178-189.

Mengel, K and Kirkby, E.A. 2001. Principles of Plant Nutrition. $5^{\text {th }}$ edition. Dordrecth: Kluwer Academic Publishers, pp: 849.

Mengel, K. 1985. Dynamics and availability of major nutrients in soils. Advances in Soil Science, 2: 65-115.

Moura, J.Z., Prado, R.M., Benvindo, R.N. and Chaves, A.L. 2013. Applying boron to coconut palm plants: effects on the soil, on the plant nutritional status and on productivity boron to coconut palm trees. Journal of Soil Science and Plant Nutrition, 13 (1): 79-85.

Muhr, G.R., Datta, N.P., Sankarasubramoney, H., Leley, V.K. and Dunabha, R.L. 1965. Soil testing in India. Second edition, USAID-Mission to India, New Delhi.

Ranade-Malvi, U. 2011. Interaction of micronutrients with major nutrients with special reference to potassium. Karnataka Journal of Agricultural science, 24 (1): 106-109.
Reuter, D. J. and Robinson, J.B. 1997. Plant Analysis: An Interpretation manual $\left(2^{\text {nd }}\right.$ edition). CSIRO Publishing

Samet, H., Cikili, Y. and Dursun, S. 2015. The role of potassium in alleviating boron toxicity and combined effects on nutrient concentrates in pepper (Capsicum annuum L.). Bulgarian Journal of Agricultural Sciences, 21 (1): 64-70.

Subbaiah, B.V. and Asija, G.L. 1956. A rapid procedure for the determination of available Nitrogen in soils. Current Science, 25: 256-260.

Venkitaswamy, R., Hameed Khan, H. and Palaniswami, C. 2011. Effect of graded levels of NPK on the reproductive characters and yield of hybrid coconut (COD X WCT). Tropical Agriculture, 86:13-20

Walkley, A. and Black, I.A. 1934. An examination of the different method for determining soil organic matter and a proposed modification of the chromic acid titration method. Journal of Soil Science, 37: 93 - 101.

\section{How to cite this article:}

Sathi Babu, N., P.S. Medda, K. Sinha and Ghosh, A. 2018. Effect of Potassium-Boron Content of Leaf on Copra Yield of Coconut (Cocos nucifera L.) in Terai Region of West Bengal. Int.J.Curr.Microbiol.App.Sci. 7(02): 398-410. doi: https://doi.org/10.20546/ijcmas.2018.702.051 